\title{
Out of Place
}

Race and Color in Jamaican Hotels, 1962-2020

\author{
Henrice Altink | ORCID: 0000-0001-9123-0722 \\ Department of History, University of York, York, U.K. \\ henrice.altink@york.ac.uk
}

\begin{abstract}
Because hotels are a microcosm of society, they offer a useful case study to explore social inequalities, including racial divisions. This article examines the experiences of African-Jamaican hotel workers and guests from independence in 1962 till the present to demonstrate the salience of Jamaica's race and color relations. It argues that hotel workers and guests at times challenged the racialized practices that they experienced but more often refrained from doing so because of their socialization into a longstanding ethos of "Black is nuh good" and exposure to a nationalist ideology that projected a vision of racial harmony. The article also shows that through their responses to claims of racial discrimination in hotels, a variety of stakeholders, including tourist organizations, failed to challenge the island's racial hierarchy which placed Whites on top, light-skinned Jamaicans in the middle, and dark-skinned Jamaicans at the bottom.
\end{abstract}

\section{Keywords}

Jamaica - racial discrimination - tourism - employment - hotels - postcolonial

In June 1972, Anthony Spaulding, minister of housing in the Jamaican government, sparked a public debate when he accused the Skyline Hotel in Kingston of racial discrimination. According to articles published in the Gleaner, Jamaica's biggest-selling newspaper, Spaulding had met some friends for a drink in the hotel bar but the waitress had refused to serve them because one of Spaulding's friends was wearing a cap and it was hotel policy for male guests to remove headwear when entering the hotel. When Spaulding had insisted that she serve his party nonetheless, she walked away saying "the worst thing when 
old nayga [person of African descent] come into people place." This in turn caused further outrage among Spaulding's party and they called for the manager. According to Spaulding, the latter had shown no intention to investigate or apologize and his conversation had "strong racial overtones." Things escalated from there and eventually the police was called. ${ }^{1}$ Since this incident involved a government minister, it led to a special cabinet meeting, which discussed this racial incident alongside other instances of "different treatment of different categories" of hotel guests and prompted Prime Minister Michael Manley to issue a statement that the government would do its utmost to counter "any form of racialism, direct or implied-even as between our own people." Reports in the paper about this incident triggered an islandwide debate about race and color discrimination that focused on but was not limited to the hotel sector.

Whether located in tourist resorts or in the capital Kingston, hotels have long provided employment to many African Jamaicans as well as services to those who visited hotels as staying guests or, who like Anthony Spaulding, went there to meet friends or conduct business. In fact, hotels, especially large foreign-owned ones, have traditionally been a means for upwardly mobile African Jamaicans to display their social status. As workers and guests, African Jamaicans have experienced discrimination in hotels: dark-skinned African Jamaicans have generally held the lower-skilled and lower-paid jobs and have struggled to take up executive posts, while as guests they have often been treated less favorably than White or light-skinned guests. This article examines both White-on-Black discrimination and colorism — skin tone discrimination-in the Jamaican hotel sector from independence in 1962 to the present, paying particular attention to the extent to which African-Jamaican hotel workers and guests have challenged these racialized practices. The article argues that through their daily actions, African-Jamaican hotel workers and guests have more often upheld rather than challenged the island's racial hierarchy that placed Whites on top, light-skinned Jamaicans in the middle, and darkskinned Jamaicans at the bottom, largely because they were socialized into a system that assigned a high value to White and light skin.

The origins of this racial hierarchy lie in slavery. Slave children fathered by White planters or overseers were given special privileges, such as exemption from field work, less violent treatment, and also more opportunities for

1 "Spaulding in Uproar at Skyline Hotel," Gleaner, June 17, 1972; "Spaulding Shocked at Show of Racial Prejudice," Gleaner, June 28, 1972.

2 “Uproar at Skyline Hotel," Gleaner, June 28, 1972. 
manumission, all on account of their closeness to White men and by definition Whiteness. ${ }^{3}$ This phenomenon, which occurred in all slave societies in the Americas, set in motion, as Margaret Hunter $(1998,2005)$ has argued, a skin color stratification process whereby a higher value was placed on people with light skin so that light-skinned people of African descent enjoyed greater privileges than their darker-skinned peers. White-on-Black discrimination and colorism, then, should be seen as two sides of the same coin. Colorism would not exist without the colonization of the Americas and the use of enslaved Africans on plantations. These two processes-colonization and slavery—led to an "ideology of White supremacy," whereby White skin came to denote positive values, such as "rationality, beauty, and superiority" and dark skin the opposite: "irrationality, ugliness, and inferiority." And this premium placed on Whiteness meant that people with light skin were more likely to be seen as intelligent or competent than those with dark skin (Hunter 2005:2$6)$.

Because of their various privileges, including manumission, long before emancipation there was already a substantial class of light-skinned free(d)men in Jamaica. With emancipation in 1838 , this class became the African-Jamaican elite because contrary to the emancipated slaves they owned houses and land, which meant that they were also able to vote and stand for election. Even though they lost their political rights after the 1865 Morant Bay rebellion when a system of Crown Colony government was adopted, they continued to occupy a status in between that of the White elite and the majority of African Jamaicans. When an elected element was added to the Legislative Council in the late nineteenth century, mostly Whites and light-skinned Jamaicans were elected. And it was also light-skinned Jamaicans who played a key role in the process that led to independence (Altink 2019a:612-613).

As Harry Hoetink has shown, the three-tier racial hierarchy that was set in motion during slavery was still firmly in place in Jamaica on the eve of independence: the less than 1 percent Whites were at the top; mostly lightskinned Jamaicans occupied the middle rung; and the majority of dark-skinned Jamaicans were firmly placed at the bottom (Hoetink 1985:72-73). This was not a caste-like structure because color intersected in complex ways with class. Dark-skinned schoolteachers or civil servants in the 196os, for example, were not placed at the bottom rung. Although it can be argued that class has become more important than color in determining social status in Jamaica in recent decades, skin color has continued to exert important effects so that even today

3 On the status of mixed-race slaves and free(d)men in Jamaica, see Heuman 1981. 
high-status positions are more likely to be held by light-skinned Jamaicans, and skin color-directly or indirectly—still informs many decisions, such as who to hire or marry.

Hotels provide an ideal setting to explore the salience of the racial hierarchy in postindependence Jamaica because they are a microcosm of society and thus reflect race and other inequalities. ${ }^{4}$ As Annabella Fick has argued, "hotels are miniatures of larger society because in their complex spatial ordering and hierarchy almost all groups of society can be found," and, because they function "as home, workplace, place of leisure, meeting place, information exchange," they reflect "the human activities" occurring in society at large (Fick 2017:36). Focusing on Jamaican hotels as places where people worked, met to conduct private business and spent their leisure time, from independence in 1962 to the present, this article shows that hotels were places where the island's racial hierarchy was manifested, contested, and upheld. In so doing, it contributes to the historical scholarship of the Anglophone Caribbean, which has largely focused on slavery and the postemancipation period but paid scant attention to the postindependence period (Bolland 2006; Brereton 2006). Moreover, while acknowledging the existence of a class-color hierarchy, Caribbean historians have largely shied away from exploring, unlike this study, the racial practices and discourses that supported this hierarchy. The very few historical studies that have addressed race in the twentieth-century Anglophone Caribbean have mentioned some of the more obvious forms of White-on-Black discrimination, such as the ceiling faced by people of African descent in the civil service (e.g. Johnson 2004), or have focused on overt resistance to racial inequality, such as Garveyism and the Black Power Movement (e.g. Quin 2015) but with few exceptions (for instance Altink 2019b; Rowe 2013; Thomas 2011) they have mostly ignored colorism and not examined how race was talked about.

This study also contributes to a wider historical scholarship on racial discrimination in the twentieth century. In recent years, this body of work has moved away from a focus on places with de jure discrimination, such as the southern states of the United States or South Africa during apartheid, to exploring racial practices and discourses in places where racial discrimination was not ordained by law. Most of this recent work has focused on Brazil, Colombia, Cuba, and other parts of Latin America (for example Appelbaum 20o3; Dávila 2003; Rodríguez-Silva 2012). This article deviates from this growing body of work in that it focuses on a majority-Black country—-throughout the postin-

4 For earlier instances where hotels formed the backdrop of an islandwide discussion about race and color discrimination, see Altink 2019b and Thompson 2006. 
dependence period, Whites made up less than 1 percent of the total population, while the Black majority hovered around 95 percent ${ }^{5}$ — with a constitution that enshrined the specific right to freedom from discrimination on account of race and color. ${ }^{6}$

While Caribbean historians have largely ignored racial practices and discourses, Caribbean social scientists have paid considerable attention to race. They have examined the ways in which "Creole nationalism" - a nonracialized nationalism that presents the nation as one people made up of different races and ethnicities living in harmony — has shaped people's understanding of racial discrimination and enabled the domination of the light-skinned middle strata in postindependence politics (for example Thame 2017; Thomas 2002 and 2004). And along with various artists and writers, including Kei Miller, Caribbean social scientists have also tried to document and/or critique more nuanced methods of racial differentiation in Jamaica and other parts of the region, such as the use of the term "classism" to refer to practices whereby (mostly) dark-skinned people receive poorer treatment (for instance Kelly \& Bailey 2018; Spencer et al. 2020) or the popularity of skin bleaching (Charles 20o9; Robinson 2011). And more recently, they have also started to quantify the influence of race on social inequality. Monique Kelly (2020), for instance, has shown that dark-skinned Jamaicans have fewer years of education and less wealth than non-Black and lighter-skinned Jamaicans. But like Caribbean historians, these scholars too have not explored in detail everyday racialized practices.

By centralizing everyday racialized practices within the Jamaican hotel sector after independence, this study also adds to tourism studies and the history of Caribbean tourism more specifically. While numerous tourism studies have explored the gendered nature of work in tourism, race has received less attention. When addressed, it tends to be the treatment of low-paid (mostly female) migrant workers in (mostly Global North) tourist hotels; the experiences of overseas White guests in majority-Black countries, particularly their sexual encounters with locals; or the commodification of race in the tourist industry, such as musical performances in resorts (Vandegrift 2008; Jamerson

5 The remaining population was made up of Chinese, people of Indian descent, Syrians, and Lebanese.

6 This right was included in the Bill of Rights that was attached to the 1962 Constitution. This made it possible for anyone, including employees, to apply to the Supreme Court but it was very expensive to do so, and such cases did not qualify for legal aid. In 2011, the Bill of Rights was replaced by a Charter of Fundamental Rights and Freedoms which made it possible for a public organization or civil society organization to launch a complaint on behalf of an individual, making it easier for poor people to seek redress. 
2016; Alberti \& Iannuzzi 2020). But this literature, with a few notable exceptions (for example Hudson et al. 2020), has largely ignored the experiences of local non-White people in tourism as workers and guests, the main focus of this article.

Frank Taylor's To Hell with Paradise: A history of the Jamaican Tourist Industry (1993) is the most comprehensive history of tourism in the Anglophone Caribbean to date. It examines the development of the Jamaican tourist industry from the late nineteenth century to the 1970s. Although this field has not been shaped by historians, various other scholars have in recent years shed light on the development of tourism in the region, including Krista Thompson, Mimi Sheller, Polly Pattullo, and Karen Wilkes. While Taylor largely glosses over the role of race in the development of the tourist industry, Thompson (2006), on which this study largely builds, explores how hotels, beaches, and other parts of the tourist sector in the decades preceding World War II were off limits to Black locals.

Sheller, Pattullo, and Wilkes have explored changes in the tourist industry since the 1980s, when many Caribbean islands, including Jamaica, witnessed a hotel boom. Although their works do not explore the everyday racialized practices in hotels, they do highlight the centrality of Whiteness to the development of Caribbean tourism. Sheller (2003), for example, demonstrates that the contribution that tourism makes to GDP in many Caribbean countries is based on the long-standing exploitation of local non-White people and local settings by White foreigners. And building on Sheller's argument, Wilkes (2016) relates the rise of the wedding industry in Jamaica to discourses and visual representations dating back to the early days of colonization that have presented the Caribbean as a site of White leisure and luxury and Black servitude.

Whiteness and coloniality are of course not just central to the Caribbean tourist industry. In many other non-White countries, ranging from Mexico and Kenya to Sri Lanka and Fiji, long-standing discourses that have exoticized the country and presented its inhabitants as subservient by nature have fueled White tourism. Even today, travel brochures featuring Global South countries are dominated by images of Whiteness-Whites as guests and managerswhile non-White men and women feature mostly as staff serving or entertaining White guests (for instance Burton \& Klemm 2011). The Raffles Hotel in Singapore and other well-known hotels where colonial elites socialized have increasingly been presented by scholars as White spaces (for example Goh 2010; Peleggi 2012; Sarmento \& Linehan 2019). Yet it could be argued that midmarket and high-end hotels in both White and non-White countries have traditionally been White spaces - as suggested by the comment made by the waitress who refused to serve Spaulding and his friends — that is, set up with White 
capital, managed by White executives, and frequented mostly by White guests. Non-White guests and non-White senior staff have always been seen as out of place. Numerous Black guests at well-known international hotels have been asked by staff to show proof that they are staying guests, ${ }^{7}$ and Black people are grossly underrepresented in hotel management (Costen et al. 2002). In the United States in 2019, for instance, Black executives made up only 1.5 percent of hospitality industry executives at director level or above. ${ }^{8}$

While this study acknowledges this wider cultural and discursive framework of Jamaican tourism, it does not aim to unpack the multiple ways in which Whiteness and coloniality have shaped the Jamaican hotel sector after 1962. Instead, it focuses on the various practices of race and color discrimination encountered by African-Jamaican hotel workers and guests, and how this was talked about in order to highlight the salience of a racial hierarchy that had its origins in slavery and colonialism and that valued non-Blackness. The study is divided into two sections, each taking a chronological approach. The first focuses on the ways in which race and color have stratified employment in the hotel sector. It demonstrates that this was done largely through race-neutral practices and that during booms in the hotel sector, African Jamaicans particularly struggled to reach senior posts. The second section explores how race and color, in close connection with class and often in very subtle ways, shaped the experiences of African-Jamaican hotel guests, particularly in their interactions with service staff. Both sections also pay attention to the ways in which government agencies responsible for overseeing the tourist industry and individual African-Jamaican politicians responded to accusations of discrimination in the hotel sector. Reliance on tourism as a major foreign exchange earner and contributor to GDP often led to the denial or downgrading of accusations of racial discrimination.

As I have argued elsewhere, race and color in independent Jamaica was and largely still is a "public secret" that is, it was commonly known that people were discriminated against on the basis of their skin color but for one reason or another this fact was rarely openly acknowledged. The unwritten rule not to talk about race and color makes it hard to find evidence of race and color discrimination. Yet fragments can be found in a variety of sources, including

7 Chris Woodyard and David Oliver, “'Do You Belong Here?': Lawsuits Allege Hilton, Other Hotels Discriminated Against Black Guests," USA TODAY, July 21, 2020, https://eu.usatoday .comBstory/travel/hotels/2020/o7/21/hilton-discrimination-lawsuits-black-guests-allege-rac ism-hotels/5405270002/ (accessed February 16, 2021).

8 For the report, "Black Representation in Hospitality Industry Leadership, 2020," see Castell Project, https://www.castellproject.org/castell-research (accessed February 16, 2021). 
sociological studies, contemporary fiction, memoirs, and newspaper accounts. This article largely relies on articles in the Gleaner, especially editorials, letters to the editor, and verbatim reports of debates in the House of Representatives and Senate. ${ }^{9}$ It uses these fragmentary qualitative sources and contextualizes them with secondary data to reveal the persistence of practices of race and color discrimination in the hotel sector in postindependence Jamaica and to show how these racialized practices have co-evolved with structural changes in the industry but were weakly affected by policy and legal shifts.

\section{Hotel Workers}

As Frank Taylor has shown, after World War II Jamaica's tourist industry rapidly expanded. On the eve of independence, it was already "the acclaimed leader in establishing mass tourism" with some 250,00o tourist arrivals per year and 74 hotels, 46 guest houses, and 106 resort cottages (Taylor 1993:159-61). Facilitated by the 1968 Hotel (Incentives) Act, additional accommodation was built to increase visitor numbers so that by 1971 there were already 119 hotels, ranging from big hotels, nearly all of which were foreign-owned, to small and locally owned venues. ${ }^{10}$ By the late 196 os, the hotel sector employed some 5,500 people (Jefferson 1972:18o), rising to 9,6oo in 1974 (World Bank 1974:13) but employment in hotels quickly declined thereafter when tourist arrivals dropped as a result of the worldwide economic recession.

In the first decade after independence, less than 1 percent of hotel staff were foreigners (Goffe 1975:29), and yet this small group of White expats occupied the top positions, such as general manager and sales manager. Assistant manager positions and front-desk posts were mostly held by light-skinned Jamaicans, while the least skilled and lowest paid positions, such as cleaners, waiters, and gardeners, were undertaken by mostly dark-skinned Jamaicans. This employment structure, which reflected Jamaica's race and color hierarchy more generally, was less the result of overt discrimination - job adverts, for instance, did not specify skin color-than implicit bias and accumulated disadvantage, that is disadvantage in one domain (such as education) having a negative impact on other domains (such as work).

9 Since it aims to demonstrate that the island's race and color hierarchy was manifested, challenged, and reinforced in hotels, this article does not discuss the treatment of AfricanAmerican guests, who over time came to make up a sizeable proportion of overseas tourist arrivals.

Jamaica Tourist Board, https://www.jtbonline.org/jtb/. 
The preponderance of expat managers in large foreign-owned hotels was strongly related to prejudices about local management competencies. But a paucity of training opportunities for local staff to reach middle-management and senior positions, which will be discussed further on, and the bias of middleclass African-Jamaican families against hotel management as a career for their children because hotels resembled plantations in their emphasis on servitude, also help to explain why there were so few non-Whites at the top (Goffe 1975:29). Local staff, especially dark-skinned staff, may also have been reluctant to pursue promotion to higher levels because they perceived that there was a ceiling beyond which they could not reach. They saw that certain posts were always given to light-skinned staff, such as front-desk manager, because staff with dark skin were not deemed "presentable enough."1 And more subtle forms of discrimination also instilled in them the idea that there was no room at the top. For example, it was common practice in international chain hotels to grant management, including heads of departments (for instance housekeeping or technical services), the privilege to use the pool, bar, dining room and other public areas when they were off-duty. In Jamaica, however, these hotels often did not extend this privilege to Black heads of departments but did grant it to White non-management staff, such as White front-desk staff. ${ }^{12}$ Many White expat managers furthermore brought racial attitudes from home with them, which may have also dissuaded African-Jamaican staff from making a career in hotels. In 1964, for instance, staff at the Shaw Park Hotel in Ocho Rios went on strike because the Polish-born wife of the British general manager, who comanaged the property with him, had called them "a lot of thieves." ${ }^{\text {"13 }}$

Because race and color discrimination was a public secret and nationalist ideology presented Jamaica as a racial paradise, very few Jamaicans openly criticized the exclusionary employment practices of hotels in the 196os and early 1970s. But it was not only the long-standing custom of not talking about race and color and nationalist ideology that explains why there was so little open criticism of the hiring practices and staff relations in the island's hotels. By 1965 , tourism already surpassed sugar as the main foreign exchange earner and annual tourist arrivals increased from 345,288 in 1966 to 414,720 in 1970 (Taylor 1993:161, 186). Because of this reliance on tourism for economic growth, politicians were reluctant to accuse hotels of race or color discrimination. A notable exception was Jamaica Labour Party (JLP) senator Austin Taylor. In 1965, he

\footnotetext{
11 "Letter to the Editor," Gleaner, August 13, 1963.

12 "You Can Quote Me," Gleaner, September 2, 1964.

13 "7o Ocho Rios Hotel Workers Go on Strike," Gleaner, August 21, 1964.
} 
complained that most hotels used expat managers while locals "worked as servants and labourers." ${ }^{14}$ Instead, politicians appealed to hoteliers to adopt training schemes that would not only enable more Jamaicans to find work in the growing hospitality sector and for some of them to reach management positions but also to provide tourists with a better experience. ${ }^{15}$

The appeals to hoteliers to provide in-house training was part of the government's policy of "Jamaicanization," which aimed to get at least $5^{1}$ percent of all shares in foreign-owned companies in local hands and more Jamaicans into management positions in these firms. In addition to calls on foreignowned firms to train locals for management positions, this policy included the 1964 Foreign Nationals and Commonwealth Citizens (Employment) Act. This act, which was particularly directed at foreign-owned banks and hotels, stipulated that non-Jamaicans had to get work permits. A permit would only be given if there was no qualified Jamaican available and only for the length of time it would take to train one. ${ }^{16}$ But the potential of the Employment Act to "Jamaicanize" and thereby "Blacken" the management of foreign-owned hotels was undermined by the government, which often succumbed to demands from hotels to allow them to hire expat labor and also dismissed demands from M P s to investigate the hiring practices of certain foreign-owned hotels. ${ }^{17}$

The government justified the granting of work permits to expat hotel staff partly by blaming Jamaicans themselves. Prime Minister Shearer, for instance, said that government was forced to give out many work permits because those who had been trained, whether at government expense or by hotels themselves, had "turned their back on us." ${ }^{18}$ But it was not just the government that helped to uphold the race and color hierarchy in hotels. One African-Jamaican manager at the Holiday Inn in Montego Bay, and a recipient of an in-house training scheme, favored the use of White expat staff until all local staff from waiters to managers had high standards of professionalism. He criticized low-level staff by stressing that they often quarreled in front of guests, thereby echoing the criticism that expat managers leveled against all Jamaican employees. ${ }^{19}$ This manager, in other words, had adopted the dominant—-that is, White—-mode of staff relations.

\footnotetext{
14 "Senate Told System Threatened with Collapse," Gleaner, July 3, 1965.

15 See, for instance, "Training Programme," Gleaner, May 22, 1964.

16 "Foreign Nationals and Commonwealth Citizens (Employment) Act," Gleaner, July 18, 1968.

17 "Work Permit Law," Gleaner, March 2, 1968.

18 "Young Radicals of the Past," Gleaner, April 13, 1970.

19 "What Goes On," Gleaner, August 13, 1973.
} 
Further limiting the Jamaicanization of management in foreign-owned hotels in the 196os and early '7os was the government's decision to persuade rather than mandate foreign-owned hotels to develop in-house training programs. Several hotels, however, did set up such programs, such as the Sheraton and Intercontinental, but the first Jamaicans to benefit from the management training schemes were rarely dark-skinned. For example, the first beneficiaries of the Sheraton training scheme, which started in 1966, included Alton MooYoung, a Chinese Jamaican, and Howard Gainair, a very light-skinned African Jamaican. ${ }^{20}$ After the training program both men attended training courses overseas and eventually became, respectively, a catering manager and a sales manager. Yet when it came to the most senior positions, the Sheraton continued to recruit expats. In 1971, for instance, it welcomed a British resident manager, a German assistant general manager, and an American director of sales. ${ }^{21}$

While some in-house training programs aimed to Jamaicanize the management of large hotels, training schemes adopted by the government, the Jamaica Tourist Board (Jтв; henceforth Tourist Board), and the Jamaica Hotel and Tourist Association (JHTA; henceforth Hotel and Tourist Association) from the late 196os onward focused on lower-level staff and aimed merely to increase their competency (Taylor 1993:177). This included a government-funded Hotel Training School set up in 1968 and operated by the Tourist Board that trained about 6 o students each year for the front desk, housekeeping, dining room, and kitchen departments in large hotels. The Tourist Board also offered a fouryear scholarship to a Swiss hotel school, while the College of Arts Science and Technology (CAST) ran a two-year Institutional Management and Catering program that trained girls for supervisory and management positions in kitchens in hotels, hospitals, and other catering institutions. ${ }^{22}$

With the exception of the CAST course, the entry requirements for these training schemes and the Tourist Board scholarship were such that it was mostly White or light-skinned Jamaicans who applied and were successful. For example, candidates for the Hotel Training School had to have higher-level school qualifications, $\mathrm{O}$ or A Levels depending on the field, and to be eligible for the Tourist Board scholarship candidates had to have basic French and ideally another foreign language. ${ }^{23}$ In other words, the programs catered for those who had attended one of the so-called traditional high schools that offered an aca-

\footnotetext{
$20 \quad$ "Jamaicans Get Sheraton Management Posts," Gleaner, November 26, 1968.

21 "Sheraton Introduces New Appointees," Gleaner, October 30, 1971.

22 "What CASt Has To Offer," Gleaner, March 5, 1962.

23 "Casa Monte To Be Hotel Training School," Gleaner, March 27, 1968; "The Ewen Scholarship for Hotel Management," Gleaner, October 9, 1965.
} 
demic curriculum. Although these schools became less exclusive in the 196os as a result of the adoption of a Common Entrance Exam (CEE) and an increase in scholarships (Altink 2019b:81-9o), the number of places was limited and it was unusual for lower-class and invariably dark-skinned boys and girls to gain a sufficiently high score in the entrance exam to be granted a scholarship. The traditional high schools were predominantly attended by middle-class and thus mostly light-skinned Jamaicans. Students on the CAST course had come from one of the island's technical high schools, which were held in less esteem than the traditional high schools. The Hotel and Tourist Association encouraged its member hotels to appoint graduates of this course for the post of receptionist but to select only those with a degree from the University of the West Indies for the in-house management trainee schemes. ${ }^{24}$ In doing so, it helped to uphold the race and color employment hierarchy of hotels since CAST students were more likely than those enrolled at the university to come from lower-class families and were on average darker.

As a result of the in-house and other training schemes and the Employment Act that required hotels to apply for work permits for foreign staff, more African Jamaicans gained management and supervisory positions in hotels in the late 196os and early '7os. For example, the dark-skinned Alvin Dennis, a graduate of William Knibb Memorial High School, started in 1966 as a trainee cottage manager at the Silver Sands Hotel. Later that year, he moved to the Half Moon Hotel where he received training in all other departments, which enabled him in turn to become the front-desk manager at Frenchman's Cove Hotel. ${ }^{25}$ Yet most of the newly hired African-Jamaican managers and assistant managers were light-skinned because of the educational requirements for the posts, and the top posts in foreign-owned hotels were still held by White expats. ${ }^{26}$ Even until the mid-197os, African-Jamaican managers and assistant managers were, as one hotel worker said, "made to feel that they are secondclass citizens." For instance, while White expat executives were given free furnished quarters, free food and drinks, free transport and their children's school fees were paid for, local executives were provided with lesser-quality furnished quarters, did not receive free food or drink nor free transport or school fees. $^{27}$

It was not until the mid- to late 1970s that dark-skinned Jamaicans began to make significant inroads in hotel management. This was the result of various

\footnotetext{
24 "UWi Students To Enter Hotel Industry," Gleaner, June 11, 1967.

25 "At the Bel Air Hotel," Gleaner, June 10, 1972.

26 "You Can Quote Me," Gleaner, November 21, 1975.

27 "The Real Trouble with Jamaica's Tourist Industry," Gleaner, January 13, 1976.
} 
factors. First, the People's National Party (PNP), which had assumed government in 1972, stepped up training schemes. The Hotel Training School began to offer two- and three-year courses in such fields as hotel accounting and hotel administration, largely to make up for the decline in in-house training schemes because many international hotel chains in the 1970s withdrew from the island. ${ }^{28}$ And in 1977, the University of the West Indies started a threeyear degree course in Hotel and Tourism Management to provide more local managers for hotels (Jayawardena 2002:9). Also various local, regional and international organizations and foreign governments offered scholarships for Jamaicans to study tourism overseas at an advanced level. The dark-skinned Hugh Wint, for instance, received a scholarship from the Organization of American States to study at the famous Schloss Klesheim in Austria and he later worked at the Upper Deck Hotel in Montego Bay. ${ }^{29}$

A second reason why African Jamaicans began to make inroads in hotel management in the mid- to late 1970s is that the PNP government assumed ownership or part ownership of several bankrupt and struggling hotels, which included the prestigious Sheraton and the Skyline. From the mid-197os, the tourist industry began to contract, which led to hotel closures and a decline in occupancy rates. This was the result of increased (political) violence and a (perceived) anti-American feeling on the island; the global economic recession which decidedly reduced the number of American visitors; and increased competition, particularly from the Bahamas and Barbados and European resorts. ${ }^{30}$ By 1980, the government owned 17 large hotels amounting to some 50 percent of all available hotel rooms. When international hotels withdrew, so did many of the top management thus opening up space for locals. While only two of the general managers of the government-owned hotels were Jamaican, all but one of the other managers were (mostly African) Jamaican. ${ }^{31}$ But African-Jamaican managers never felt fully accepted in this traditionally White sector. They, for instance, were convinced that the Hotel and Tourist Association - set up in 1961 by hotel operators and thus a White-led organization-did not include them in discussions about the development of the sector. Some, in fact, even accused the organization of being "racist."32 The Hotel and Tourist Association denied

28 Ministry of Industry, Tourism and Foreign Trade 1976:6-7. The school ceased to exist in 1978 when a centralized system of on-the-job training for hotels was adopted.

29 "Career Hotelier Returns to Runaway Bay heART Hotel," Gleaner, February 22, 2006.

30 Tourist arrivals declined from 553,258 in 1975 to 386,514 in 1977 (Taylor 1993:186).

$31 \quad$ "Who Looks After Tourism?," Gleaner, July 16, 1978.

32 "Tourism," Gleaner, December 19, 1976. 
such accusations by stating that it had done more than any other organization to facilitate the rise of Black hotel managers. ${ }^{33}$

The 1980 elections resulted in a JLP government led by Edward Seaga, which was determined to make tourism a major engine of economic growth. A Ministry of Tourism was set up and attempts were made to lease, and later also sell, government-owned hotels to private operators. In addition, various schemes were adopted to encourage the building of new hotels or the upgrading of existing ones (Chambers \& Airey 2001:110). The economic recovery in North America and Europe, the devaluation of the Jamaican dollar, a decline in violence and a more aggressive campaign by the Tourist Board facilitated an increase in tourist arrivals of some 50 percent between 1981 and 1985 (McCatty \& Serju 2006:6). As a result, by 1983 tourism had become a key source of foreign currency for the economy. This expansion in tourism led to an increase in the number of people employed in hotels from 9,527 in 1980 to 16,336 in 1987-from 1.3 to 1.9 percent of the total employed labor force (World Bank 1989:98). The tourist industry suffered a setback in 1988 when Hurricane Gilbert struck but the industry bounced back in the early 1990s, when cruise tourism and the number of all-inclusive resorts increased, and the PNP, which had assumed government in 1989, continued the policy of its predecessor to adopt policies to encourage foreign direct investment (FDI) in tourism. Most of the all-inclusive resorts were owned or leased by foreign companies with the exception of the Sandals and SuperClubs resorts. By the end of the decade, some 1 million people visited Jamaica annually, nearly double the number in the 1980s, and hotels employed some 30,ooo staff (World Bank 2004:154, 192).

Both the JLP and PNP governments in the 1980s and 'gos realized the importance of investing not just in tourism's infrastructure, such as hotels and resorts, but also in human resources. To remedy a shortage of skilled staff and supported by USAID, the World Bank, and the Organization of American States, the JLP government set up the Runaway Bay HEART Academy and Hotel in 1986. ${ }^{34}$ The HEART Academy offered short courses for entry-level positions, taking mostly students from nontraditional high schools. In addition, the publicly funded University of the West Indies began to offer additional degrees in tourism, including a four-year program jointly offered with CAST's successor the University of Technology (UTech) and accredited by the world's largest hotel management association. A variety of private educational providers also

33 “JHTA Replies to Gleaner 'Allegations,"' Gleaner, December 27, 1976.

34 "Most of the Tourist \$ Stays Here," Gleaner, November 14, 1987. 
offered certificates, diplomas, and degrees in hospitality and tourism in the 1980s and '9os, such as the Western Hospitality Institute in Montego Bay. It was not until 1999, however, before the University of the West Indies, with EU funding, started an MSc in hospitality and tourism management aimed at staff already working in the sector, who wanted to reach middle-management and senior positions (Hall, Holder \& Jayawardena 2002:11-12).

This proliferation of training helped to "Blacken" hotel management. ${ }^{35}$ For example, the executive assistant manager, sales manager, and the director of sales at the Jamaica Grande, a 720-room hotel and convention center that opened in 1992, were all dark-skinned women. ${ }^{36}$ But those who entered middlemanagement positions with a degree, which increasingly became an essential criterion for management positions in the 1980 os and ' 9 os, tended to be lighterskinned than those who had worked their way through the ranks after having entered the sector after their secondary education because they came from better-off families and had attended traditional high schools. For example, when a refurbished Courtleigh Hotel opened its doors in 1997, the light-skinned University of the West Indies graduate Ann Marie Hibbert joined as its accounts manager, while the dark-skinned Owen Codling, who had started at the hotel in 1966 as a waiter, was appointed as its maintenance manager. ${ }^{37}$

But while more and more African Jamaicans obtained middle-management positions in the 1980s and '9os, the top positions in the hotel sector, such as general manager of an all-inclusive resort, were nearly always held by White expats with the exception of top positions in Jamaican-owned chains. Sandals, for instance, actively recruited Jamaicans for top positions, including those who had migrated and worked in hotels overseas. ${ }^{38}$ Also many White expat managers continued to hold perceptions of Jamaican staff that drew upon long-standing racial stereotypes, in particular the idea that Black people are inherently lazy. One expat manager, for instance, complained that it took a Jamaican chamber maid eight hours to clean nine rooms, whereas American maids cleaned double the rooms in that time. ${ }^{39}$ Some expat managers also created divisions between expats and local staff. Both at the Wyndham and the Half Moon hotels, for instance, White expat managers made Jamaican staff use a separate entrance. ${ }^{40}$

"Conflating Colorism with Quality in Jamaica's Hotel Industry," Gleaner, October 27, 2019.

36 "Women at the Top," Gleaner, March 14, 1993.

37 "The Senior Managers," Gleaner, September 26, 1997.

38 "Sandals Catering to Returning Jamaicans," Gleaner, September 14, 1992.

39 "Problems Facing Jamaican Hotels," Gleaner, August 16, 1985.

40 "Letter to the Editor," Gleaner, December 7, 1994. 
For PNP senator Charles Sinclair, the decision of Half Moon's general manager Franz Eichenhauer in 1985 that Jamaican staff had to use a separate entrance was indicative of the systematic harassment and discrimination faced by workers of "dark complexion" at the resort and he asked government to investigate..$^{41}$ This led to a public debate, on talk radio among others, which extended beyond the specific case at the Half Moon and focused as much on intra-staff relations as on staff-guest relations. ${ }^{42}$ While many participants in this debate agreed that relations between expat and local staff were not always harmonious, hardly any referred to this as racial discrimination. In fact, the chair of the St Ann Parish Council's Tourism Committee fervently denied that he had accused North Coast hotels of "racism" when he noted the "ratio of expatriate staff to local personnel," and mentioned that many of the former actually treated the latter with "diffidence." ${ }^{\text {33 }}$ Because of the widespread debate, the Minister of Tourism asked the Tourist Board to investigate. The latter concluded that the general manager of the Half Moon, who resigned shortly after the hotel's management had received the Tourist Board's report, had displayed a "harsh and at times undiplomatic attitude which was not conducive to harmonious relations between management and staff" but that he had not practiced "racial discrimination." 44 Thus again we see, the reluctance to describe relations between White expat staff and non-White local staff in terms of race as a result of the long-standing rule not to talk about race and also because of Jamaica's nationalist ideology which upheld a vision of racial harmony.

Since the turn of the twenty-first century, continuous FDI in Jamaican hotels has led to multinational corporations now owning 6o percent of Jamaica's tourism assets (World Bank 2004:154; Stupart \& Shipley 2013:15). Especially Spanish chains, such as RIU, Fiesta, and Iberostar, have heavily invested in Jamaica and they now dominate the all-inclusive sector. In 2018, there were 203 hotels, including 74 all-inclusives that accounted for 79.4 percent of all hotels rooms. ${ }^{45}$ The Spanish and other foreign-owned hotel chains are increasingly accused in the media of flouting environmental and building codes, bribing politicians, and catering for a lower class of visitors that bring additional prob-

\footnotetext{
41 "Hotel Discrimination?," Gleaner, August 30, 1985.

42 “JHtA Passes Anti-Racism Resolution," Gleaner, September 5, 1985.

43 "Report Charging Hotel Racism Denied," Gleaner, October 25, 1985.

44 "Half Moon Cleared of Racism Charge," Gleaner, September 20, 1985.

45 Jamaica Tourist Board, Annual Travel Statistics 2018, https://www.jtbonline.org/report -and-statistics/ (accessed February 16, 2021).
} 
lems for local communities (Stupart \& Shipley 2013:15). Yet rarely mentioned in the criticisms of these hotels are the relations between their expat managers and local staff.

When the Spanish hotels first opened, the most senior posts were held by Spanish and other White expats. This was largely explained by management as a means to "infuse company culture and systems." ${ }^{\text {I }}$ It is indeed common practice for international hotel chains to initially favor their own staff over locals for senior posts in order to maintain the "policies and culture of the parent firm" (Xu, Ye \& Chan 2018:30). This reliance on outsiders has caused frictions. Expat staff, for instance, were often given more privileges than local staff. At Fiesta's Palladium Hotel, Spanish managers could eat in the restaurant and get day passes for their family but not Jamaican staff. And one female employee of the hotel complained that after she had trained up Spanish staff, she was passed over for promotion (McFarlane-Morris 2017:108).

Even several years after they were set up, many of the top positions in the Spanish hotels were still held by White expats. For example, in 2010 the German Katarina Doehler, who had worked at several RIU hotels in Jamaica, became general manager of the RIU Montego Bay when Frank Sondern, another German, was promoted to RIU's regional director. ${ }^{47}$ And in 2011, the managing director, the resident manager, and the general manager of the Iberostar Rose Hall Hotel were all White expats. ${ }^{48}$ That expats continue to occupy the top positions in foreign hotels illustrates that mid-market to high-end hotels are still largely White zones. Reinforcing this racial exclusivity is a lack of trained local managers, which the World Bank has listed as one of the main constraints facing the Jamaican tourism sector, and can be attributed to the lack of higher-level training in tourism in Jamaica (World Bank 2011:29). Since the turn of the century, tertiary institutions have not significantly expanded their graduate and postgraduate programs in hotel management and some of these programs are very expensive: the Northern Caribbean University, for instance, charges US $\$ 1,588$ tuition per semester for its BSc program in Hospitality and Tourism Management. ${ }^{49}$ Middle-class parents also still dislike hotel management as a career option for their children, while teachers often steer pupils away from tourism (Crick 2008:83). As a result, most Africans Jamaicans who

\footnotetext{
46 "Letter to the Editor," Gleaner, October 13, 2008.

47 "Jamaica's Youngest Female Hotel Manager," Gleaner, October 13, 2010.

48 “Jamaica's Jazz \& Blues Festival Pictorial," Gleaner, February 2, 2011.

49 Northern Caribbean University, NCU Tuition \& Fees (Approximate), https://www.ncu.edu .jm/Tuition2020_2021_final.pdf (accessed February 16, 2021).
} 
occupy middle-management positions in Spanish and other foreign-owned hotels today have a degree in hospitality from a local tertiary institution and at least several years' working experience. Educational provision and prevailing attitudes toward the hotel trade, then, have facilitated the racially exclusive employment structure of the hotel sector.

But lack of trained staff is not the only reason why there are so few locals at the top in recently built foreign hotels. Illustrating how much Whiteness and coloniality continue to shape the tourism industry, various studies have shown that local and foreign guests at international chain hotels in developing countries prefer a foreign manager (Situmorang \& Japutra 2019:69). Also welltrained African Jamaicans continue to experience a glass ceiling in the hotel sector because of their race. In 2015, for instance, Sam James, a well-known African-Jamaican hotelier was bypassed for the role of managing director of the Tryall Club, a luxury villa resort and private members club. The club's board argued that its decision to appoint the White naturalized Jamaican Aram Zerunian was based on merit: he had a "unique skills set" to manage the resort and club. Because James had an MA in hotel management and 44 years' experience of managing large hotels and had been the managing consultant for Tryall, he was convinced that his skin color had been the main deciding criterion used by the nearly all-White board. ${ }^{50}$ As Howard Adler and Juliane Rigg have shown in their exploratory study of the perceptions of expat hotel managers in Jamaica about the various human resource, operational and organizational issues they face, many expat managers still doubt the managerial qualities of local staff and some also hold racialized views of local staff, complaining about their low productivity (Adler \& Rigg 2012:5).

Training for entry-level positions has increased since the turn of the century, especially in areas that have seen significant Spanish investment. ${ }^{51}$ Most of this training is provided by the Human Development and Resource Training Trust/National Training Agency (HEART Trust/NTA). In September 2011, the Gleaner published an article claiming that HEART/NTA specified light skin for trainees for front-desk positions, which sparked a huge public debate. ${ }^{52}$ The HEART Trust/NTA was ordered by the public defender to reveal the names of the hotels that had made these requests. HEART Trust/NTA denied that it had received formal requests for light-skinned trainees. It added to this another common rhetorical strategy to deny racial discrimination by declaring

$5^{\circ} \quad$ "Racism at Tryall," Gleaner, February 1, 2015; "Rubbish!," Gleaner, February 8, 2015.

$5^{1} \quad$ "Hannover Prepared for Hospitality Jobs," Gleaner, July 2, 2011.

$5^{2}$ "Brownings Please," Gleaner, September 13, 2011. 
a commitment to racial equality. The organization stressed that its aim was to train "all working-age Jamaicans, regardless of gender, colour or class."53

Thus throughout the postindependence period, there has been a racial divide in Jamaican hotels with White expats occupying the most senior posts and African Jamaicans occupying the rest. This divide narrowed somewhat in the late 196os and ' 70 os as government took more oversight of the hiring and training of staff through Jamaicanization and nationalization policies so that more African Jamaicans were able to take up middle- and senior management posts. The building of many large-scale foreign-owned hotels in recent years, however, has entrenched the long-standing racialized nature of work in the hotel sector since these resorts have brought in many expat managers. Also since middle- and senior-management positions require at least an undergraduate degree and several years' experience, when locals hold such positions, they are mostly light-skinned Jamaicans because of the long-standing close connection between class, color, and education in Jamaica. For example, the light-skinned Kerry-Ann Casserly, who has an MA in business from a private university in Florida, was for several years director of sales at Iberostar Rose Hall. ${ }^{54}$

Some may argue that work in Jamaican hotels is not marked by a racial divide because employment decisions are based on race-neutral criteria, such as qualifications and experience. But as the case of Sam James illustrates, factors other than merit often play a role in hiring decisions. And it should also be stressed that the appointment of nearly all White expats in senior posts exerts racial effects. Above all, it reinforces long-standing racial ideas that associate light skin with intelligence and superiority, and dark skin with incompetence and inferiority. As the following section shows, these ideas have also informed the experiences of African-Jamaican guests and their relations with local service staff.

\section{Hotel Guests and Visitors}

As a result of the expansion of secondary and tertiary education and economic growth, more African Jamaicans moved into the middle class in the 1960 and ' $70 s$, including many dark-skinned men and women. New prestigious hotels were places where they could demonstrate their new class status. Like

53 "HeART Not Responding," Gleaner, October 2, 2011.

54 Kerry-Ann Casserly's LinkedIn page, https://www.linkedin.com/in/kerry-ann-quallo-cas serly-7a2b5379/?originalSubdomain=jm (accessed February 16, 2021). 
Anthony Spaulding, they met friends in hotels for drinks or dinner, and some even booked a short stay at a North Coast hotel. Because hotels were traditionally White zones, middle-class African Jamaicans faced barriers in accessing them. First and foremost, high rates. Room rates in North Coast hotels were high because they catered for well-off foreign tourists. The hotels also charged more for drinks and dinner than local bars and restaurants. In the early 197os, the price of a bottle of Coca Cola in a hotel was almost five times that of the average price in the area (Graham 1975:48). It was also not uncommon for hotels to charge locals for the use of their facilities. For example, even if they had only drinks or dinner at the poolside bar, they had to pay to use the hotel pool as well. When one African-Jamaican guest refused to do so at the Trident Hotel in Port Antonio, the White owner remarked "Damn black people ... who don't know where they are not wanted," ${ }^{55}$ which illustrates that charging extra for facilities was a means to keep hotels White.

In addition to high rates, various unwritten rules also made hotels less than welcoming spaces for African Jamaicans. It was, for instance, not uncommon for African-Jamaican guests to be told that there was no record of their reservation and many were refused entry to the restaurant or bar for not complying with the dress code. ${ }^{56}$ Such unwritten rules were largely policed by AfricanJamaican service staff, who were also generally less courteous with local Black guests. For example, when one African-Jamaican woman complained about being quoted the prices of her drinks in American currency, the waiter retorted, "Why don't you go to the bar downtown and get $7 \mathrm{~d}$ cokes?"57 And note that it was the waitress in the Skyline incident who asked one of Spaulding's friends to remove his hat in line with hotel rules. But even during the worldwide economic recession of the 1970s when attempts were made to stimulate the domestic tourism market through such means as the Tourist Board's "Discover Jamaica" campaign and the adoption of "Jamaican room rates," 58 service staff were still reluctant to give African-Jamaican guests "the red carpet."59 In 1979, for instance, a Mr. Bertram who had stayed regularly at the Holiday Inn on business trips was refused accommodation by the night manager who had also called him names. ${ }^{60}$

\footnotetext{
55 "You Can Quote Me," Gleaner, November 21, 1975.

56 See, for instance "You Can Quote Me," Gleaner, November 21, 1975 and "Letter to the Editor," Gleaner, April 10, 1982.

57 "Letter to the Editor," Gleaner, August 27, 1969.

$5^{8}$ This had some effect: in 1977, for instance, 131,089 Jamaicans stayed in hotels (Taylor 1993:184).

59 "Playing the Numbers," Gleaner, December 2, 1976.

6o "Letter to the Editor," Gleaner, November 21, 1979.
} 


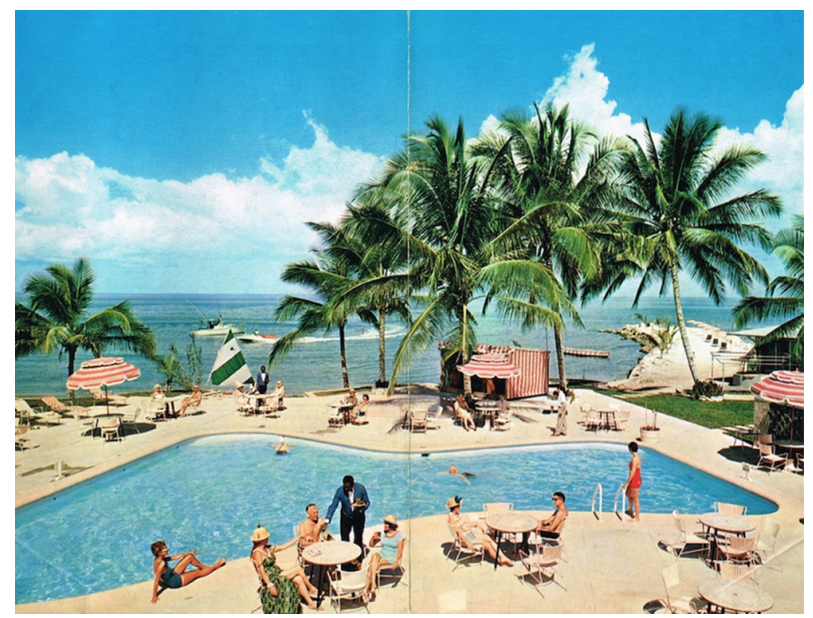

FIGURE 1 Golden Head Beach Resort, Ocho Rios, 1966 HTTP://JAMAICAHOTELHISTORY.COM/

BROCHURES/, ACCESSED FEBRUARY 16, 2021, PERMISSION OBTAINED FROM DON WISS, THE WEBSITE OWNER

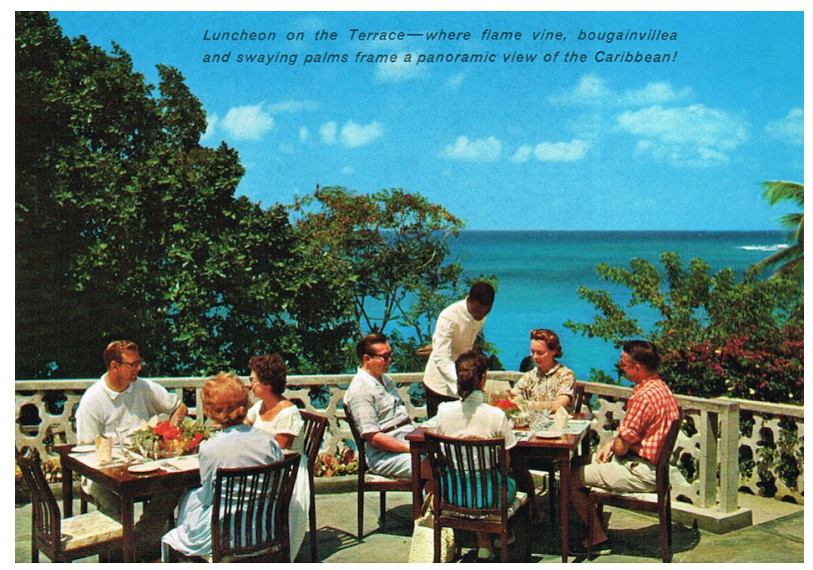

FIGURE 2 A brochure from Plantation Inn, Ocho Rios, 1965 HTTP://JAMAICAHOTELHISTORY.COM/ BROCHURES/, ACCESSED FEBRUARY 16, 2O21, PERMISSION OBTAINED FROM DON WISS, THE WEBSITE OWNER 
Hotel brochures for large hotels from the 1960s usually featured an allWhite, foreign clientele and Black service staff, as illustrated in Figures 1 and 2. Through these brochures but even more so through the long-standing association of hotels as White spaces, Black service staff came to define tourists as White foreigners and this may explain why many were so discourteous to local non-White guests. But waiters and other service staff also complained that African-Jamaican guests were rude because they did not know how to behave in hotels. ${ }^{61}$ As newcomers to the middle class, many African-Jamaican guests may indeed have struggled to understand the unwritten hotel etiquette. Yet tensions between African-Jamaican guests and service staff in the 196os and ' 70 os should also be seen in light of the island's class and color relations. Initially most African-Jamaican hotel guests came from the traditional light-skinned middle class but by the 1970s the number of dark-skinned local guests increased. The status of dark-skinned Jamaicans, who through education and occupation had moved into the middle class, was insecure because they had moved into a space traditionally occupied by light-skinned Jamaicans. To secure their status, many came to look down upon those below them and tried to distance themselves from them, while also trying to adopt the values and practices of those above them - both the White elite and the traditional light-skinned middle class-including socializing in hotels. So the rudeness of local Black guests encountered by waiters and other service staff may also reflect this disregard of many dark-skinned, middle-class Jamaicans for those at the bottom of the social ladder.

The long socialization into the ethos "Black is nuh good," which dated back to slavery, furthermore, meant that dark-skinned newcomers to the middle class were not held in high regard by either the traditional light-skinned middle class or by the mostly dark-skinned working class (Altink 2019b:116-30). The waitress who refused to serve Spaulding and his friends, for example, referred to them as "nayga," a racial epithet used by the lower classes to refer to someone "uneducated and incompetent" (Austin 1984:144-45). She, in other words, did not see Spaulding and his friends as rightfully belonging within the White, middleclass space of the hotel. Or to put it differently, for the waitress their education and occupation did not mitigate their dark skin. ${ }^{62}$

When African-Jamaican guests complained that treatment received by service staff amounted to racial discrimination, management usually responded

$61 \quad$ "Some Local Guests Steal from Hotels," Gleaner, July 29, 1979.

62 Two months after the Spaulding incident, the Skyline Hotel made headlines again when a dark-skinned man was thrown out of the hotel bar for not taking off his hat. "Refused To Take off Hat," Gleaner, August 25, 1972. 
that staff had merely followed hotel rules or that they lacked interpersonal skills. ${ }^{63}$ The internal investigation into the Spaulding case by Skyline's management, for instance, concluded that the waitress had not been rude let alone racially motivated. She had simply asked a guest to obey a rule that applied equally to all guests - in a "number of instances" White men had also been asked to remove their hats. ${ }^{64}$ And Holiday Inn's management claimed that the night manager had simply followed the hotel's rules but admitted that he had not handled the Mr. Bertram situation "as tactfully as he should have."65 Considering the importance of tourism to the economy, both the JLP and PNP governments in the 196os and '7os were keen to convey that race and color discrimination had no place in the hotel industry. They stressed that robust methods were in place to prevent hotel workers from discriminating against guests on the basis of race or color: a hotel's license could be revoked if it was found to discriminate on account of "colour, race, origin and politics," and any cases of racial discrimination reported would be "dealt with in 24 hours." 66

One such accusation of discrimination reached the Director of Tourism in February 1969 when Pearnel Charles, a trade union official, complained that it was "on account of his colour" that he had been told to leave the Beach View Hotel in Montego Bay, one of the oldest and largest hotels on the North Coast. ${ }^{67}$ The Tourist Board investigated the complaint and concluded that Pearnel Charles had been treated in an "offensive and discriminatory" manner. Not only did the organization carefully avoid the words race or color but it also minimized Pearnel Charles' claim of racial discrimination by stressing that this was "not typical of the policy of the hotel." In other words, the Tourist Board presented this as a one-off, nonracial incident rather than a structural issue. When the Tourist Board's report was published, White hotel owner Trevor Edwards further denied that race or color had anything to do with the incident by invoking the equality principle: "It is the policy of the hotel to welcome all Jamaicans irrespective of colour, class or creed." ${ }^{\prime 6}$

63 "Carib-Ocho Rios Manager Apologizes to uwi Guild," Gleaner, December 9, 1969; "Problems Facing Tourism Discussed," Gleaner, December 13, 1970.

64 "Hotel Owners Investigate," Gleaner, July 4, 1972.

65 "Letter to the Editor," Gleaner, November 21, 1979.

66 "Jamaica Has Maintained Upward Trend in Tourism," Gleaner, July 14, 1969; "The Challenge of Tourism," Gleaner, October 28, 1972. There is no record, however, that any hotel had its license revoked or suspended on account of race or color discrimination.

67 "Beach View Hotel Incident," Gleaner, February 13, 1969.

68 "Tourist Board Reports on Charles Incident," Gleaner, September 5, 1969. This was a very common justification to brush aside complaints by local guests. See, for instance, "Letter to the Editor," Gleaner, September 6, 1969. 
When international tourist arrivals began to increase in the early 1980 os, attempts to boost domestic tourism ceased and this affected the treatment of African-Jamaican guests. It was not uncommon in the 1980 os and '9os for guests on Jamaican room rates to be given the least attractive rooms. ${ }^{69}$ In addition, security staff would often turn away local guests, while waiters, bar tenders, and entertainment staff lavished more attention on foreign than local guests. ${ }^{70}$ This discriminatory behavior was not just driven by a desire for tips-foreign guests were allegedly better tippers ${ }^{71}$ - but also because service staff, and the population more broadly, continued to associate tourists with White foreigners (Dunn \& Dunn 2002:36-38). And so not just local but also foreign Black guests were treated less courteously than White foreign guests. ${ }^{72} \mathrm{~A}$ survey conducted in 1999, for example, found that local Black guests were treated even worse than foreign Black guests (Dunn \& Dunn 2002:38).

That African-Jamaican guests were effectively third-class citizens (after White and Black foreign tourists) in hotels in the 199os is largely because African Americans constituted a significant proportion of American tourists that visited the island. During that decade, tourist receipts grew by 5 percent annually and some 65 percent of stop-over tourists came from the United States (World Bank 2004:154). It could be argued, then, that for service staff, wealththe tourist dollar-mitigated to some extent skin color. As Osagie K. Obasogie has concluded in his study of blind people's understanding of race, it is not the case that "racial differences become salient merely because they are selfevident and visually obvious" but "social practices produce the ability to see and experience race in particular ways" (Obasogie 2014:4). It was not uncommon for African Jamaicans to see people as lighter than they were if they considered them to be a member of the better class, based on their occupation, education, and other class markers, including speech and dress. Yet the "Black is nuh good" ethos meant that wealth did not always mitigate color. For instance, many domestic servants preferred to work for White or light-skinned rather than dark-skinned families (Altink 2019b:119).

But the rudeness with which some service staff treated African-Jamaican guests may also have been a way for them to vent their frustration with the fact that these men and women had moved up the social ladder, while they

69 See, for instance, "Letter to the Editor," Gleaner, April 7, 1986.

$70 \quad$ "Letter to the Editor," Gleaner, September 12, 1985; "Harassment in Ocho Rios," Gleaner, June 1,1987 .

71 See, for instance, "Your Hotel Stay," Gleaner, August 23, 1989.

72 See, for example, "The Lingering Spectre of Colonialism," Gleaner, November 9, 1990; “Tourism Survey-Part Two," Gleaner, November 12, 199 o. 
were still stuck at the bottom. And this frustration should be seen in light of the growing inequality in Jamaica. Increased tourist arrivals were a main driver of economic growth in the 199os and this in turn led to greater income inequality: the Gini coefficient, which measures the deviation of income distribution among individuals or households from an equal distribution, increased from 35.70 in 1993 to 44.10 in $1999 .{ }^{73}$

Even though the Tourist Board and Hotel and Tourist Association were by then mostly led by African Jamaicans, these organizations remained relatively silent in the 1980 os and 'gos on the discriminatory behavior of service staff toward local Black guests. Occasionally, the Tourist Board and Hotel and Tourist Association reminded hotels that they could lose their license if they were seen to discriminate on account of race or color. ${ }^{74}$ But because tourism accounted for 10 percent of Jamaica's GDP (World Bank 2004:154), the organizations were reluctant to undertake concrete action to improve the treatment of local Black guests. Hence, they and many others who directly benefited from the tourist industry, including hotel proprietors, managers and also many service staff, tried to minimize claims of racial discrimination. Similar justifications as in the 1960s and ' 70 os were provided to explain the poor service offered to local Black guests: White guests were better tippers; local Black guests were not accustomed to hotels; and service staff lacked training in interpersonal skills. ${ }^{75}$ They also tended to avoid racial language, talking instead of "perceived discriminatory practices" toward "Jamaicans" or "locals." And they also minimized claims of racial discrimination by stating that it was only "a few" hotel workers who had shown "prejudicial behaviour."76

But it was not just the subtle means of discrimination that put many African Jamaicans off from visiting or staying in large hotels in the 1980 os and ' 9 os. When overseas tourist arrivals began to increase in the 1980 , room rates went up, including Jamaican room rates. In the early $1980 \mathrm{os}$, a room in a North Coast hotel easily cost US $\$ 25$. This along with a dinner plan of US\$15 was out of reach for many African Jamaicans, including teachers and civil servants. ${ }^{77}$ African Jamaicans found it particularly hard to visit the all-inclusive resorts that were

73 World Bank Development Research Group, Gini index (World Bank estimate) Jamaica, https://data.worldbank.org/indicator/SI.POV.GINI?locations=JM\&view=chart (accessed February 16, 2021).

"Our Freedoms and Cuba's," Gleaner, March 6, 1982; "Strengthening the Tourist Industry," Gleaner, November 14, 199 o.

"Your Hotel Stay," Gleaner, August 23, 1989; “Are Black People Tourists?," Gleaner, November 31, 1997 .

76 See, for instance, "Deal with All Visitors Equally," Gleaner, April 17, 1998.

77 “Our Freedoms and Cuba's," Gleaner, March 6, 1982. 
built from the 1980s onward. Unless they were staying guests, they could only access them by paying a hefty day rate. Even today, a day pass is out of reach for many. Most resorts now charge US\$65 per person, which includes drinks and food and access to the pools, beach, and other facilities. ${ }^{78}$

The 2008-9 global financial crisis reduced the number of US tourists, which made up the bulk of tourist arrivals, by 3.3 percent. ${ }^{79}$ To counteract this and more generally to boost the tourism sector amidst a financial crisis, the Tourist Board and Hotel and Tourist Association launched the "Experience Jamaica" campaign to encourage more locals to vacation at home. But even though the organizations presented this stimulation of domestic tourism as a long-term strategy, ${ }^{80}$ they did not use the definition of tourist outlined in the Ministry of Tourism's 2002 Master Plan for Sustainable Tourism: “Anyone who travels away from home (country, parish, town) for a stay of one or more nights for holidays, visits to friends or relatives, business, conferences or any other similar purpose" (Dunn \& Dunn 2002:38; italics are mine). Instead, they continued to see tourists first and foremost as White overseas visitors. In fact, even today, the Tourist Board's annual travel statistics only provide data of overseas visitors so that Jamaicans who holiday in any of the beach resorts are still not seen as tourists. In a video that circulated on social media in 2018, a White foreign tourist complained that her local Black friend was discriminated against while they were visiting Port Antonio. Responses to the video by African Jamaicans echoed her comments; various respondents mentioned that waiters did not offer local Black guests welcome drinks and that other service staff also treated them rudely. ${ }^{81}$ Yet the Tourist Board and Hotel and Tourist Association and others directly benefiting from tourism continue to deny that local Black guests are still treated as second- or third-class citizens. ${ }^{82}$

As during previous economic downturns, it is likely that the decline in overseas tourists resulting from the CoviD-19 pandemic will trigger another cam-

78 "No Beach for Local Tourists," Gleaner, January 8, 2015. There has been much discussion in recent years about the negative impacts of "enclave tourism," which stresses the economic, environmental but also social costs, including the existence of poor areas close to the hotels; the impact on local businesses such as taxi drivers and restaurant owners, who usually lose out when all-inclusives are developed; and the wage rates in all-inclusive hotels which are often lower than that of other hotels. See, for instance, Saarinen 2017 and Freitag 1994.

79 See Jamaica Tourist Board, Annual Travel Statistics 2008 and 2009, https://www.jtbonline .org/report-and-statistics/ (accessed February 16, 2021).

8o "Minister Urges Jamaicans To Take Staycations," Gleaner, September 28, 2009.

81 "Modern-day plantations," Gleaner, February 28, 2018.

82 "Concerns Raised About Image of Local Tourism," Gleaner, February 13, 2013. 
paign to stimulate domestic tourism. This section has suggested that any campaign will need to be accompanied by training for hotel workers to understand that tourists include not only White foreigners, but also Black foreigners and locals. But even with such training, many African-Jamaican guests may continue to experience second- or even third-class service because they are out of place in a traditionally White zone, and Black service staff have been socialized into a system that places a premium on White and light skin. Since many Jamaicans will lose their job during the pandemic recession and may have to seek a job in a hotel far below their skills level, it should also not be ruled out that service staff may vent their frustration of being stuck in low-skilled, lowpaid jobs by treating African-Jamaican guests with less courtesy than overseas guests.

\section{$3 \quad$ Conclusion}

Hotels are private properties subject to state regulation, and they include not just private rooms but also public areas - the lobby, the bar, the restaurant, the pool, and so on (Craggs 2012:216). They are, then, a gray zone between private and public (Davidson 2018:3). Furthermore, while they are governed by the same laws and conventions that affect our ordinary lives, they are also extraordinary places and places of anonymity, where "normal social conventions can be challenged and flouted"-people do things in hotels they would normally not do, such as stealing remote controls. Hotels represent "borderlands between the mundane and the extraordinary" and between the private and the public. For these reasons, they have been described as "liminal spaces," where "dominant discourses and wider hegemonic socio-cultural relations are resisted, contested or affirmed" by different stakeholders including guests, managers, and service staff (Pritchard \& Morgan 2006:763-765; italics are mine).

The foregoing has shown that Jamaica's hegemonic race and color relations, which place a premium on White and light skin, have been resisted and contested within hotels since independence in 1962. Anthony Spaulding and Pearnel Charles, among others, openly contested their right to be in the traditionally White space of the hotel and used overt racial language. But access to this space has always been largely policed by African-Jamaican service staff, who in doing so helped to affirm the island's race and color relations. And many African-Jamaican guests, especially upwardly mobile guests whether light- or dark-skinned, have also done so through their patronizing treatment of the mostly dark-skinned service staff. But African-Jamaican staff have at times if 
not contested than at least nibbled away at the race and color hierarchy in hotels. Some, for instance, went on strike when a White manager called them names, while others availed themselves of training opportunities so that they could apply for posts traditionally held by White expat staff.

And the foregoing has also demonstrated that the island's dominant racial discourses have been "resisted, contested or affirmed" during racial incidents in hotels or in public debates about these incidents. Most stakeholders, however, carefully avoided the words race or color and suggested that it was class, a lack of training, or anything else but race that explained why some guests or staff were treated worse than others. Some, on the other hand, did not deny that race or color discrimination took place in hotels but downplayed it by attributing it to a few bigoted individuals, who were the exception not the rule. Yet some stakeholders, especially African-Jamaican guests, did not hesitate to describe their experiences as racial discrimination, as the sources carefully documented in this article have shown. In doing so, they violated the long-standing unwritten rule not to talk about race and color and also punctured the myth of racial harmony espoused by nationalist ideology.

Throughout the postindependence period, African Jamaicans have struggled to obtain the most senior posts in hotels. In fact, it has become even harder for them since the turn of the century with the building of many large foreign-owned all-inclusive resorts that have relied mostly on White, expat managers. As these resorts charge high rates, even to use the public areas, African Jamaicans find them difficult to access as staying guests or visitors. Many have referred to all-inclusive resorts in Jamaica and elsewhere in the region as the new plantations (for example Pattullo 1996; Wong 2015). In fact, starting in the 1970s with dependency theorists such as George Beckford (1972), it has been argued that the tourist industry in the Caribbean mirrors the sugar plantations. First, like plantations, resorts are owned by foreign entities and profits generated do not stay in the islands and hence contribute little to local development. Second, as on the plantations African-descended people working in resorts render services to White foreigners. And third, resorts have a similar racialized occupational structure as sugar plantations, with White expats managing the place for absentee White owners, dark-skinned Caribbean people doing the most menial work for which they get paid little, and mostly light-skinned people undertaking the relatively well-paid middle-management positions.

Thus since the 1970s many critics of the Caribbean tourist industry have described it as racially divisive and exploitative. But what they fail to acknowledge is that the race relations that were established with the formation of the plantation system in the seventeenth century have continued to inform race 
and color relations on the islands today. This affects not just how local Black service staff treat White foreign guests but also how they relate to local Black guests and how they themselves are treated by Black guests. By unpacking the relations between local Black guests and service staff, this article has shown that the hotel sector is even more racially divisive than previously acknowledged. Having been socialized in a system that devalues dark skin and having been exposed since independence to a myth of racial harmony, local Black staff and guests have at times resisted and contested the island's dominant racial discourses and relations but more often affirmed them.

But the tendency to affirm rather than challenge dominant racial discourses and relations should also be seen in light of the fact that hotels in non-White postcolonial states have traditionally been White spaces. It could be argued that the Whiteness of the hotel rubbed off on African-Jamaican hotel workers and guests. Thus some African-Jamaican managers came to hold the same stereotypes of Black service staff_-as lazy and unreliable—as the White managers before them, while Black service staff displayed the status gained from working in a traditionally White space in their relations with local guests, who were new to hotels. And middle-class African Jamaicans who visited hotels, largely to emulate the practices of those above them and thus display a degree of Whiteness, expected the same level of service as White guests and therefore berated Black service staff when not given it.

Because the dominant racial discourses and relations have their origin in slavery and colonialism and affect all areas of life, and hotels in postcolonial states have traditionally been White spaces, changing staff training materials to include a wider definition of tourists or other measures to improve relations between local Black guests and service staff are unlikely to achieve the desired impact. While Jamaica can do little to change the perception of hotels as White spaces, which dates back to the colonial era, it can confront the long-standing public secret of race and color and the nationalist myth of racial harmony, and adopt measures to create a more level playing field for men and women of different skin tones so that the hotel sector will become less racially divisive.

The anthropologist Michael Taussig, who coined the term public secret many years ago, has argued that key to the power of a public secret is that it is never fully revealed (Taussig 1999:5). There are some hopeful signs that the public secret of race and color in Jamaica may be losing its power. In the past, few people dared to openly state that Jamaica was effectively a pigmentocracy-a society in which lightness bestows status-because those who did, were often vilified. In response to the George Floyd killing in Minneapolis in May 2020, however, various Jamaicans went on social media to publicly state that racism 
and colorism were rife in their country. It remains to be seen whether this will encourage politicians to take action to create a more level playing field but the fact that the public secret is now being revealed by a large segment of society is a positive step forward.

\section{Acknowledgments}

I wish to thank my colleague David Clayton for his insightful comments on an earlier version of this article. Also, thanks to the anonymous reviewers, who pushed me to think about hotels as zones of Whiteness.

\section{References}

Adler, Howard \& Juliane Rigg, 2012. Expatriate Hotel General Managers in Jamaica: Perceptions of Human Resource, Organizational and Operational Challenges. Journal of Hotel and Business Management 1(1). [DOI: 10.4172/2169-0286.1000104.]

Alberti, Gabriella \& Francesco E. Iannuzzi, 2020. Embodied Intersectionality and the Intersectional Management of Hotel Labour: The Everyday Experiences of Social Differentiation in Customer-Oriented Work. Gender Work and Organization $27(6): 165-8$ o.

Altink, Henrice, 2019a. "Marrying Light": Skin Colour, Gender and Marriage in Jamaica, c. 1918-1980. The History of the Family 24(3):608-628.

Altink, Henrice, 2019b. Public Secrets: Race and Colour in Colonial and Independent Jamaica. Liverpool: Liverpool University Press.

Appelbaum, Nancy P., 2003. Muddied Waters: Race, Region and Local History in Colombia, 1846-1948. Durham NC: Duke University Press.

Austin, Diane J., 1984. Urban Life in Kingston, Jamaica: The Culture and Class Ideology of Two Neighborhoods. New York: Gordon and Breach.

Beckford, George L., 1972. Persistent Poverty: Underdevelopment in Plantation Economies of the Third World. Oxford: Oxford University Press.

Bolland, O. Nigel, 20o6. Historiography of Decolonization in the Anglophone Caribbean. In Juanita de Barros, Audra Diptee \& David V. Trotman (eds.), Beyond Fragmentation:Perspectives on Caribbean History. Princeton NJ: Markus Wiener, pp. 26596.

Brereton, Bridget, 2006. Recent Developments in the Historiography of the PostEmancipation Anglophone Caribbean. In Juanita de Barros, Audra Diptee \& David V. Trotman (eds.), Beyond Fragmentation: Perspectives on Caribbean History. Princeton NJ: Markus Wiener, pp. 187-209. 
Burton, Dawn \& Mary Klemm, 2011. Whiteness, Ethnic Minorities and Advertising in Travel Brochures. Service Industries Journal 31(5):679-693.

Chambers, Donna \& David Airey, 2001. Tourism Policy in Jamaica: A Tale of Two Governments. Current Issues in Tourism 4(2-4):94-120.

Charles, Christopher A.D., 20o9. Skin Bleachers' Representation of Skin Color in Jamaica. Journal of Black Studies 40(2):153-70.

Costen, Wanda M., Alison G. Cliath \& Robert H. Woods, 2002. Where Are the Racial and Ethnic Minorities in Hotel Management? Exploring the Relationship Between Race and Position in Hotels. Journal of Human Resources in Hospitality \& Tourism $1(2): 57-69$.

Craggs, Ruth, 2012. Towards a Political Geography of Hotels: Southern Rhodesia, 19581962. Political Geography 31(4):215-24.

Crick, Anne P., 2008. No Plantation Work Here: Contemporary HR Practices in Caribbean Hotels. International Journal of Contemporary Hospitality Management 2O(1):79-89.

Davidson, Robert A., 2018. The Hotel: Occupied Space. Toronto: University of Toronto Press.

Dávila, Jerry, 2003. Diploma of Whiteness: Race and Social Policy in Brazil, 1917-45. Durham NC: Duke University Press.

Dunn, Hopeton S. \& Leith L. Dunn, 2002. Tourism and Popular Perceptions: Mapping Jamaican Attitudes. Social and Economic Studies 51(1):25-45.

Fick, Annabella, 2017. New York Hotel Experience: Cultural and Societal Impacts of an American Intervention. Bielefeld, Germany: Transcript Verlag.

Freitag, Tilman G., 1994. Enclave Tourism Development for Whom the Benefits Roll? Annals of Tourism Research 21(3):538-554.

Goffe, Peter, 1975. Development Potential of International Tourism. Cornell Hotel and Restaurant Administration Quarterly 16(3):24-31.

Goh, Daniel P.S., 2010. Capital and the Transfiguring Monumentality of Raffles Hotel. Mobilities 5(2):177-95.

Graham, Floyd Albert, 1975. Physical Planning Objectives and Strategies for Minimizing Exclusiveness in Resort Areas in Jamaica. MA Thesis, Massachusetts Institute of Technology, Cambridge MA.

Hall, Kenneth O., Jean S. Holder \& Chandana Jayawardena, 2002. Caribbean Tourism and the Role of UWI in Tourism and Hospitality Education. Social and Economic Studies 51(1):145-65.

Heuman, Gad J., 1981. Between Black and White: Race, Politics and the Free Coloreds in Jamaica, 1792-1865. Oxford: Clio Press.

Hoetink, H., 1985. "Race" and Color in the Caribbean. In Sidney W. Mintz \& Sally Price (eds.), Caribbean Contours. Baltimore MD: Johns Hopkins University Press, pp. 5584 . 
Hudson, Simon, Kevin Kam Fung So, Fang Meng, David Cárdenas \& Jing Li, 202O. Racial Discrimination in Tourism: The Case of African-American Travellers in South Carolina. Current Issues in Tourism 23(4):438-51.

Hunter, Margaret L., 1998. Colorstruck: Skin Color Stratification in the Lives of African American Women. Sociological Inquiry 68(4):517-35.

Hunter, Margaret L., 2005. Race, Gender and the Politics of Skin Tone. New York: Routledge.

Jamerson, W. Trevor, 2016. Race and Critical Tourism Studies: An Analytical Literature Review. Sociology Compass 10(11):1038-45.

Jayawardena, Chandana, 2002. Tourism and Hospitality Education and Training in the Caribbean. Kingston: University of the West Indies Press.

Jefferson, Owen, 1972. The Post-war Economic Development of Jamaica. Mona, Jamaica: Institute of Social and Economic Research, University of the West Indies.

Johnson, Howard, 2004. The Black Experience in the British Caribbean in the Twentieth Century. In Phillip D. Morgan \& Sean Hawkins (eds.), Black Experience and the Empire. Oxford: Oxford University Press, pp. 317-46.

Kelly, Monique D.A., 2020. Examining Race in Jamaica: How Racial Category and Skin Color Structure Social Inequality. Racial and Social Problems 12:300-12.

Kelly, Monique D.A., \& Stanley R. Bailey, 2018. Racial Inequality and the Recognition of Racial Discrimination in Jamaica. Social Identities 24(6):688-706.

Mccatty, Machel \& Prudence Serju, 2006. Tourism, Economic Growth \& Employment. [Kingston]: Bank of Jamaica. [Working Paper https://cert-net.com/files/publicati ons/conference/918.pdf.]

Mcfarlane-Morris, Shenika A., 2017. The Other Side of the Enclave: Local Perspectives on the Onset of Mass Tourism in Jamaica. Ph.D. Dissertation, University of Western Ontario, London

Ministry of Industry, Tourism and Foreign Trade, 1976. Report of the Activities of the Tourism Product Development Company for 1975/76. [Kingston]: Government of Jamaica. [Ministry Papers no. 23. https://nlj.gov.jm/MinistryPapers/.]

Obasogie, Osagie K., 2014. Blinded by Sight: Seeing Race Through the Eyes of the Blind. Stanford CA: Stanford University Press.

Pattullo, Polly, 1996. Last Resorts: The Cost of Tourism in the Caribbean. London: Cassell.

Peleggi, Maurizio, 2012. The Social and Material Life of Colonial Hotels: Comfort Zones as Contact Zones in British Colombo and Singapore, ca. 1870-1930. Journal of Social History 46(1):124-53.

Pritchard, Annette \& Nigel Morgan, 2006. Hotel Babylon?: Exploring Hotels as Liminal Sites of Transition and Transgression. Tourism Management 27(5):762-772.

Quinn, Kate (ed.), 2015. Black Power in the Caribbean. Gainesville: University Press of Florida. 
Robinson, Petra Alaine, 2011. Skin Bleaching in Jamaica: A Colonial Legacy. Ph.D. Dissertation, Texas A\&M University, College Station.

Rodríguez-Silva, Ileana M., 2012. Silencing Race: Disentangling Blackness, Colonialism and National Identities in Puerto Rico. New York: Palgrave Macmillan.

Rowe, Rochelle., 2013. Imagining Caribbean Womanhood: Race, Nation and Beauty Competitions, 1929-1970. Manchester: Manchester University Press.

Saarinen, Jarkko, 2017. Enclavic Tourism Spaces: Territorialisation and Bordering in Tourism Destination Development and Planning. Tourism Planning and Development 19(3):425-37.

Sarmento, João \& Denis Linehan, 2019. The Colonial Hotel: Spacing Violence at the Grande Hotel, Beira, Mozambique. Environment and Planning D: Society \& Space 37(2):276-93.

Sheller, Mimi, 2003. Consuming the Caribbean: From Arawaks to Zombies. London: Routledge.

Situmorang, Ringkar \& Arnold Japutra, 2019. Foreign Versus Local Managers: Finding the Perfect Leaders for Multinational Hotel Subsidiaries. International Journal of Hospitality Management 78:68-77.

Spencer, Nekeisha, Mikhail-Ann Urquhart \& Patrice Whitely, 2020. Class Discrimination? Evidence from Jamaica: A Racially Homogenous Labor Market. Review of Radical Political Economics 52(1):77-95.

Stupart, Copeland A. \& Robert Shipley, 2013. Jamaica's Tourism: Sun, Sea and Sand to Cultural Heritage. Journal of Tourism Insights 3(1). [https://doi.org/10.9707/2328 -0824.1028.]

Taussig, Michael T., 1999. Defacement: Public Secrecy and the Labor of the Negative. Stanford CA: Stanford University Press.

Taylor, Frank Fonda, 1993. To Hell with Paradise: A History of the Jamaican Tourist Industry. Pittsburgh PA: University of Pittsburgh Press.

Thame, Maziki, 2017. Racial Hierarchy and the Elevation of Brownness in Creole Nationalism. Small Axe 21(3):111-23.

Thomas, Deborah A., 2002. Democratizing Dance: Institutional Transformation and Hegemonic Re-ordering in Postcolonial Jamaica. Cultural Anthropology 17(4):5125o. [https://doi.org/10.1525/can.2002.17.4.512.]

Thomas, Deborah A., 2004. Modern Blackness: Nationalism, Globalization, and the Politics of Culture in Jamaica. Durham NC: Duke University Press.

Thomas, Deborah A., 2011. Exceptional Violence: Embodied Citizenship in Transnational Jamaica. Durham NC: Duke University Press.

Thompson, Krista A., 2006. An Eye for the Tropics: Tourism, Photography, and Framing the Caribbean Picturesque. Durham NC: Duke University Press.

Vandegrift, Darcie, 2008. "This Isn't Paradise-I Work Here”: Global Restructuring, the Tourism Industry, and Women Workers in Caribbean Costa Rica. Gender \& Society 22(6):778-798. 
Wilkes, Karen, 2016. Whiteness, Weddings, and Tourism in the Caribbean: Paradise for Sale. New York: Palgrave Macmillan.

Wong, Alfred, 2015. Caribbean Island Tourism: Pathway to Continued Colonial Servitude. Études Caribéennes 31-32. [https://doi.org/10.40oo/etudescaribeennes/7524.] WORLD BANK, 1974. Jamaica-Current Economic Position and Prospects (Vol. 2): Annexes 1 \& 2: Population, Labor Force, Employment, and Tourism (English). Washington DC: World Bank Group. [http://documents.worldbank.org/curated/en/17984146 8044161974/Annexes-1-2-population-labor-force-employment-and-tourism.]

WORLD BANK, 1989. Jamaica-Adjustment Under Changing Economic Conditions (English). Washington DC: World Bank Group. [http://documents.worldbank.org/ curated/en/986881468039008497/Jamaica-Adjustment-under-changing-economic -conditions.]

WORLD BANK, 2004. The Road to Sustained Growth in Jamaica (English). Washington DC:World Bank Group. [http://documents.worldbank.org/curated/en/59324146 8752950633/The-road-to-sustained-growth-in-Jamaica.]

WORLD BANK, 2011. Jamaica-Country Economic Memorandum: Unlocking Growth (English). Washington DC: World Bank Group. [http://documents.worldbank.org/ curated/en/920121468042544307/Jamaica-Country-economic-memorandum-unlo cking-growths.]

$\mathrm{Xu}$, Honggang, Tian Ye \& David Chan, 2018. When Cosmopolitan Corporations Meet Local Environments: The Impact on Managerial Structure in International Luxury Hotels. International Journal of Hospitality Management 74:30-39. 